Dawid TALER ${ }^{1}$

Pawel MADEJSKI ${ }^{2}$

Jan TALER ${ }^{3}$

\title{
MODELOWANIE USTALONYCH PROCESÓW PRZEPLYWOWO-CIEPLNYCH W KOTLE FLUIDALNYM
}

\begin{abstract}
W pracy zostały przedstawione wyniki komputerowej symulacji pracy przegrzewacza pary w stanach ustalonych. Analizowany przegrzewacz charakteryzuje się złożonym kształtem przekroju poprzecznego rur i jest stosowany w kotłach z cyrkulującą warstwą fluidalną. W trakcie obliczeń cieplno-przepływowych niezbędne jest wyznaczanie rozkładu temperatury materiału na całej długości przegrzewacza. Do przeprowadzenia obliczeń pracy przegrzewacza w stanach ustalonych stworzono własny model matematyczny, napisany w języku Fortran, którego wyniki zostały porównane z wynikami otrzymanymi w programie Star-CCM+. W modelu własnym zastosowano bilansową metodę elementów skończonych, która pozwala na dokładne odwzorowanie rozkładu temperatury przy niewielkiej liczbie komórek siatki. Do wyznaczenia właściwości przepływającej pary została zastosowana jawna metoda różnic skończonych. Wyniki uzyskane z zastosowaniem opracowanego własnego modelu wykazały się bardzo dobrą zgodnością z wynikami uzyskanymi dzięki modelowaniu CFD.
\end{abstract}

Słowa kluczowe: kocioł parowy, pole temperatury, komputerowa mechanika płynów, bilansowa metoda elementów skończonych

\section{Wstęp}

W pracy został wykonany model matematyczny przegrzewacza pary pierwotnej drugiego stopnia, zbudowanego z rur ,podwójna omega”. Przegrzewacz $\mathrm{z}$ tego typu rur jest stosowany w kotłach z cyrkulacyjnym złożem fluidalnym, jako przegrzewacz grodziowy zlokalizowany nad komorą paleniskową. Rysunek 1. przedstawia pojedynczą grodź przegrzewacza składającą się z 27 sekcji, do których jest doprowadzana para. Każda sekcja składa się z trzech biegów, co daje łączną liczbę rur w każdej grodzi równą 81. Para do 27 sekcji przegrzewa-

\footnotetext{
${ }^{1}$ Autor do korespondencji/corresponding author: Dawid Taler, Politechnika Krakowska, ul. Warszawska 24, 31-155 Kraków, tel.: (12) 6283600, e-mail: dtaler@pk.edu.pl.

2 Paweł Madejski, Akademia Górniczo-Hutnicza, e-mail: madejski@agh.edu.pl.

${ }^{3}$ Jan Taler, Politechnika Krakowska, e-mail: taler@mech.pk.edu.pl.
} 
cza jest doprowadzana przez komorę pośrednią wlotową. Para, przepływając przez daną sekcję, dokonuje dwóch nawrotów, zanim trafi do komory pośredniej wylotowej. Każda sekcja przegrzewacza jest zbudowana z trzech biegów różniących się między sobą wartością średnicy wewnętrznej oraz materiałem, z jakiego zostały wykonane. Rysunek 2. przedstawia widok pojedynczej sekcji z zaznaczonymi poszczególnymi biegami wykonanymi ze stali $15 \mathrm{Mo} 3,13 \mathrm{CrMo} 44 \mathrm{i}$ 10CrMo910, odpowiednio dla biegu I, II oraz III.

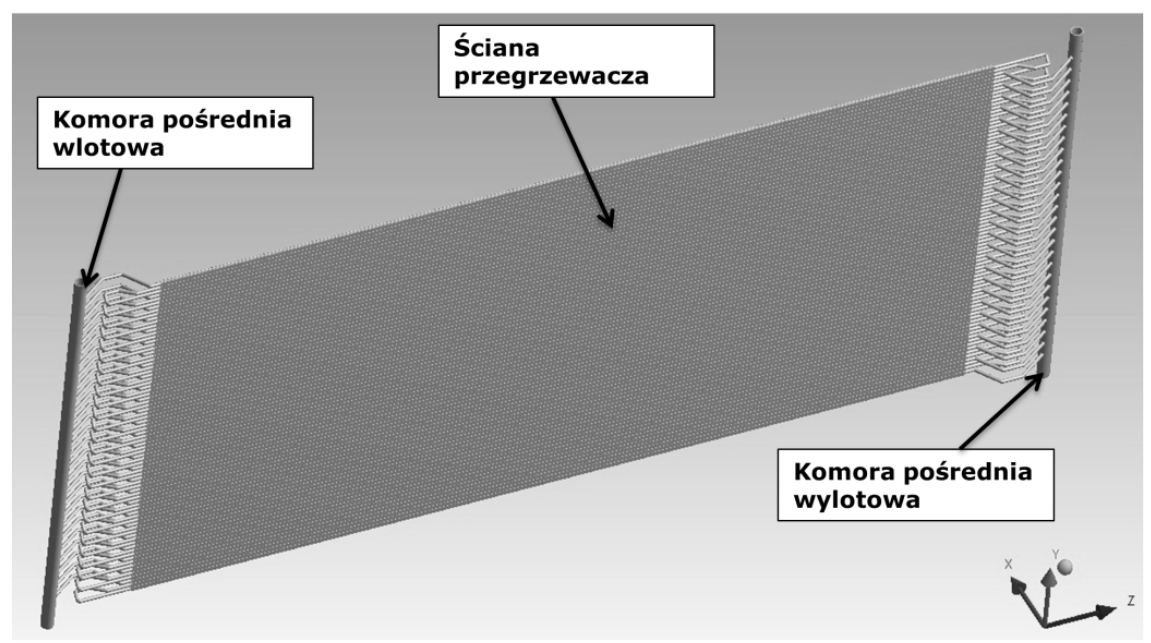

Rys. 1. Pojedyncza grodź przegrzewacza zbudowanego z rur „podwójna omega”

Fig. 1. A single plate of a superheater built with „,double omega” tubes

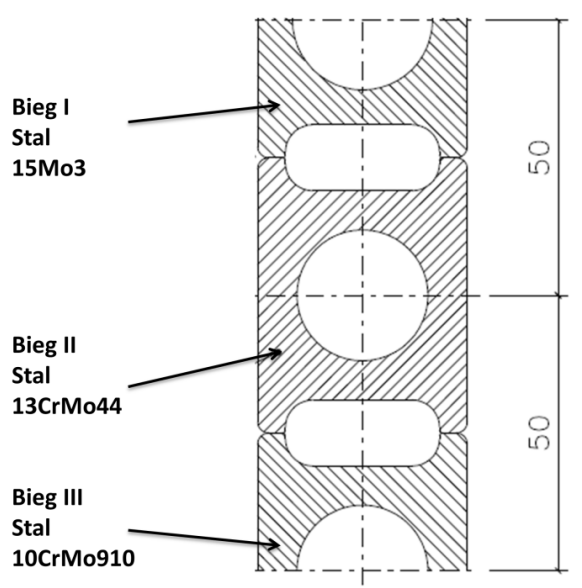

Rys. 2. Przekrój poprzeczny przez 3 biegi przegrzewacza

Fig. 2. Cross-section of the 3 passes of a superheater 


\section{Matematyczny opis zjawisk przepływowo-cieplnych w przegrzewaczu pary}

W celu przeprowadzenia analiz przepływowo-cieplnych w stanach ustalonych wykonano model numeryczny odwzorowujący zjawiska zachodzące podczas pracy przegrzewacza. W wykonanym modelu numerycznym została odwzorowana para przepływająca przez wszystkie trzy biegi przegrzewacza oraz materiał przegrzewacza, z uwzględnieniem zmiany średnicy wewnętrznej. Właściwości termofizyczne pary oraz materiału ścianki były wyznaczane $\mathrm{w}$ trakcie obliczeń we wszystkich elementach, na jakie został podzielony przegrzewacz. Do wyznaczania właściwości wykorzystano funkcje temperatury i ciśnienia (para) [7] oraz temperatury materiału (ścianka przegrzewacza) [2].

Zjawiska zachodzące podczas przepływu pary odwzorowano z wykorzystaniem odpowiednio zdefiniowanych równań różniczkowych dla zasady zachowania masy, pędu i energii. Zjawiska przybliżono modelem jednowymiarowym, uwzględniającym zmiany właściwości i parametrów pary tylko w kierunku przepływu czynnika. Rysunek 3. przedstawia pojedynczy obszar kontrolny, dla którego są rozwiązywane równania zachowania masy, pędu i energii.

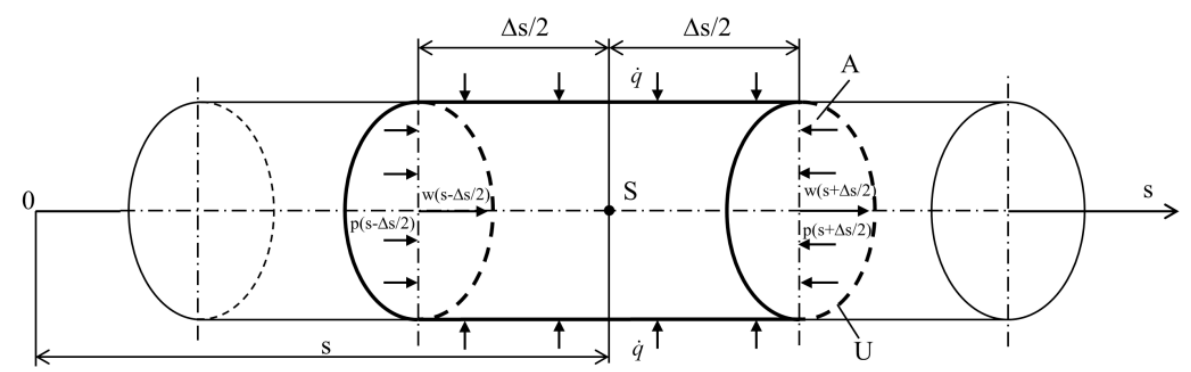

Rys. 3. Obszar kontrolny z zaznaczonymi wartościami prędkości $w$, ciśnienia $p$ oraz gęstości strumienia ciepła $\dot{q}$

Fig. 3. The control area with marked values of velocity $w$, pressure $p$ and heat flux density $\dot{q}$

Równanie zachowania masy wykorzystane w modelu przedstawia się następująco:

$$
\frac{\partial \dot{m}}{\partial s}=0
$$

gdzie: $\dot{m}$ - strumień masy pary, $s$ - współrzędna kierunkowa przechodząca przez środek ciężkości przekroju poprzecznego rury. 
Równanie zachowania pędu dla przepływającej pary ma postać:

$$
\frac{\partial p}{\partial s}=-\rho w \frac{\partial w}{\partial s}-\frac{\xi}{d_{h}} \frac{\rho w|w|}{2}
$$

gdzie: $p$ - ciśnienie pary, $\rho$ - gęstość pary, $w$ - prędkość pary, $\xi$-współczynnik strat tarcia, $d_{h}$ - średnica hydrauliczna.

Równanie zachowania energii dla pojedynczego obszaru kontrolnego przedstawia wzór:

$$
\rho c_{p}\left(\frac{\partial T}{\partial t}+w \frac{\partial T}{\partial s}\right)=\frac{1}{A} \int_{0}^{U} \alpha_{1}\left(\left.T_{w}\right|_{r=r_{w}}-T\right) \mathrm{d} U
$$

gdzie: $c_{p}$ - ciepło właściwe pary przy stałym ciśnieniu, $T$ - temperatura pary, $U$ - obwód przekroju o polu poprzecznym, $A$ - pole przekroju, $\alpha_{1}$ - współczynnik wnikania ciepła po stronie pary, $T_{w}$ - temperatura wewnętrznej powierzchni ścianki zmieniająca się na obwodzie $U, r_{w}$ - promień wewnętrzny rury.

Zastosowanie całki po prawej stronie równania (3) wynika ze złożonego kształtu przekroju poprzecznego rury. Na wewnętrznej powierzchni kanału gęstość strumienia ciepła nie jest stała, z uwagi na nierównomierny rozkład temperatury na wewnętrznej powierzchni kanału. Do wyznaczenia wartości temperatur i ciśnienia pary została zastosowana jawna metoda różnic skończonych. Każdy bieg przegrzewacza podzielono na 20 obszarów kontrolnych, w których obliczono parametry pary. Wykorzystane w modelu równanie przewodzenia ciepła dla stanów nieustalonych przyjmuje następującą postać:

$$
c(T) \rho(T) \frac{\partial T}{\partial t}=\frac{\partial}{\partial x}\left[\lambda(T) \frac{\partial T}{\partial x}\right]+\frac{\partial}{\partial y}\left[\lambda(T) \frac{\partial T}{\partial y}\right]
$$

gdzie: $c$ - ciepło właściwe materiału, $\rho$ - gęstość materiału, $T$ - temperatura materiału, $\lambda$ - współczynnik przewodzenia ciepła, $\mathrm{W} /(\mathrm{m} \cdot \mathrm{K})$.

Rozkład temperatury w elemencie o tak złożonym kształcie przekroju poprzecznego wyznaczono bilansową metodą objętości skończonych [5, 6]. Zastosowanie tej metody dla przekroju poprzecznego przegrzewacza wymaga podziału poszczególnych przekrojów poprzecznych na objętości kontrolne (rys. 4.). Ponieważ każdy bieg przegrzewacza jest wykonany z innego materiału i posiada inną średnicę wewnętrzną, podziału dokonano osobno dla każdego biegu. W opracowanym modelu wartości temperatury materiału są wyznaczane w 11 punktach (rys. 4.), w 20 przekrojach poprzecznych rury dla każdego biegu przegrzewacza. 
a)

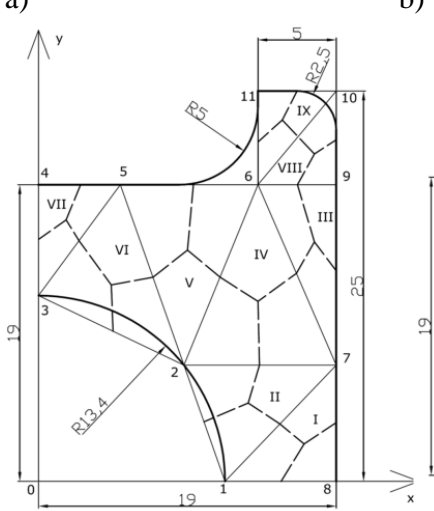

b)

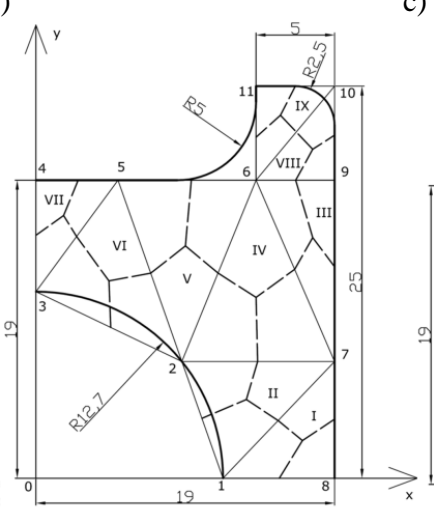

c)

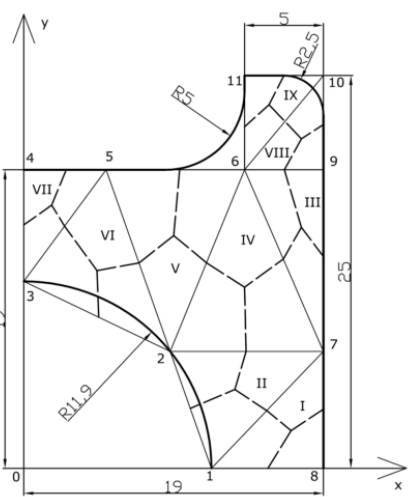

Rys. 4. Podział przekroju poprzecznego pierwszego (a), drugiego (b) i trzeciego (c) biegu przegrzewacza na objętości kontrolne

Fig. 4. The division of the cross-section of the first (a), second (b) and third (c) pass of a superheater on control volumes

Współczynnik wnikania ciepła po stronie pary $\alpha_{1}$ jest obliczany w każdym obszarze kontrolnym za pomocą wzoru:

$$
\alpha_{1}=\frac{\mathrm{Nu} \cdot w}{d_{h}}
$$

gdzie Nu oznacza liczbę Nusselta, która jest wyznaczana z wykorzystaniem korelacji Gnielinskiego [1, 4, 7], obowiązującej dla zakresów liczb Reynoldsa $3 \cdot 10^{3} \leq \operatorname{Re} \leq 10^{7}$ i Prandtla $0,5 \leq \operatorname{Pr} \leq 200$ :

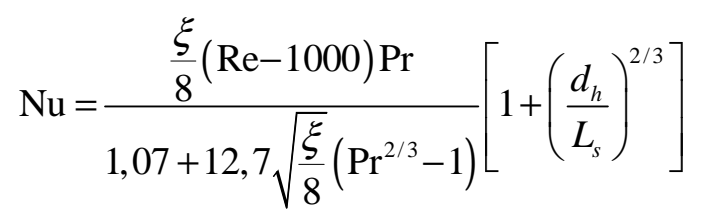

gdzie $L_{s}$ - długość jednego biegu przegrzewacza.

Współczynnik strat tarcia $\xi$ występujący we wzorze (6) oraz w równaniu zachowania pędu (2) jest obliczany z zależności $[4,7]$ :

$$
\xi=\frac{1}{(0,79 \ln \operatorname{Re}-1,64)^{2}}
$$


Współczynnik wnikania ciepła po stronie spalin $\alpha_{2}$ został dobrany tak, aby wartość temperatury pary na wylocie z całego przegrzewacza zgadzała się z wartością zmierzoną. $\mathrm{Z}$ uwagi na różnice $\mathrm{w}$ odwzorowaniu geometrii $\mathrm{w}$ modelu własnym i programie Star-CCM+, wartości współczynników posiadają niewielką różnicę.

\section{Model CFD przegrzewacza pary}

W celu wykonania weryfikacji obliczeń przepływowo-cieplnych dla przegrzewacza składającego się z trzech biegów wykonany został numeryczny model z zastosowaniem pakietu Star-CCM+ [3], wykorzystującego w obliczeniach metodę objętości skończonych.

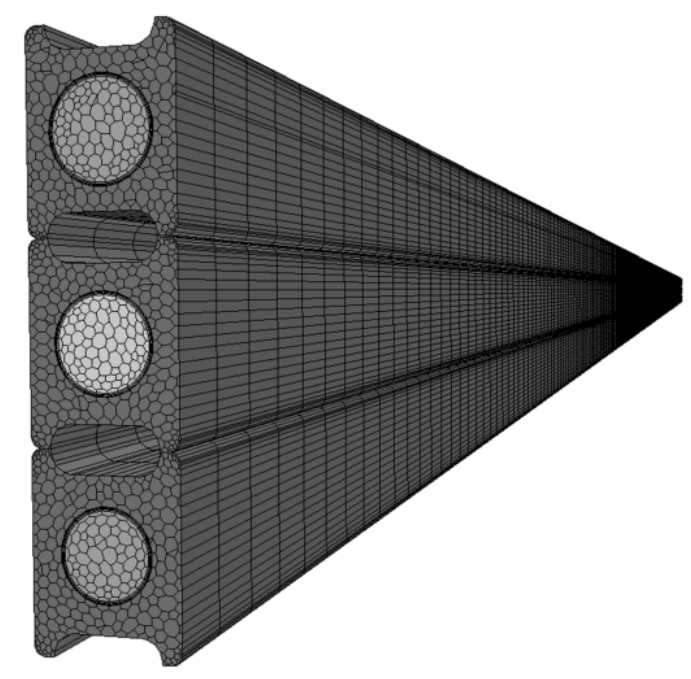

Rys. 5. Siatka numeryczna wykorzystana $\mathrm{w}$ obliczeniach $\mathrm{Z}$ zastosowaniem programu Star-CCM+

Fig. 5. The numerical mesh used in the calculations using the Star-CCM + program

Wszystkie trzy biegi przegrzewacza zostały podzielone na łączną liczbę elementów pary i ścianki równą 437170 (rys. 5.). W modelu wymiana ciepła pomiędzy materiałem przegrzewacza a przepływającą parą została zamodelowana jako sprzężona wymiana ciepła. W każdym punkcie na powierzchni wewnętrznej rury temperatura płynu i materiału oraz bezwzględna wartość gęstości strumienia ciepła są takie same. Do zamodelowania zjawiska turbulencji wykorzystano 2-równaniowy model $k-\varepsilon$. Temperatura na wlocie do II i III biegu została obliczona za pomocą średniej masowej temperatur, wyznaczonych na powierzchniach zewnętrznych komórek siatki płynu na wylocie z biegu poprzedniego. Właściwości termofizyczne pary zostały uwzględnione w modelu w postaci funkcji temperatury i ciśnienia [7], a materiału biegów przegrzewacza w postaci funkcji temperatury [2]. 


\section{Obliczenia przegrzewacza pary dla różnych obciążeń kotła}

W celu weryfikacji opracowanych modeli zostały przeprowadzone obliczenia ustalonej pracy przegrzewacza dla trzech różnych obciążeń kotła: 100, 60 i $35 \%$. Dla wyznaczonych na drodze pomiaru parametrów pracy kotła wykonano obliczenia przegrzewacza $\mathrm{z}$ wykorzystaniem własnego modelu oraz modelu wykonanego w pakiecie Star-CCM+. Tabela 1. przedstawia wartości parametrów przyjętych do obliczeń dla trzech różnych analizowanych wydajności kotła. Zmiany temperatury pary i maksymalnej temperatury materiału $\mathrm{w}$ postaci przebiegów na długości całego przegrzewacza przedstawiają rys. 6-8. Wyniki w postaci zmiany temperatury pary w kierunku jej przepływu przez wszystkie trzy biegi przegrzewacza są identyczne (100 i 60\%) zarówno przy stosowaniu modelu opierającego się na MOS, jak i na BMES. Niewielkie różnice w wartościach temperatury pary, nieprzekraczające $2 \mathrm{~K}$, w zastosowanych modelach wykazuje przypadek, kiedy wydajność kotła jest równa 35\% wydajności znamionowej. Obliczone temperatury pary na wylocie z poszczególnych biegów (przyrost temperatury pary) oraz maksymalna temperatura materiału uzyskana z wykorzystaniem dwóch modeli (MOS i BMES) są bardzo do siebie zbliżone. Niewielkie różnice $\mathrm{w}$ wartościach maksymalnej temperatury ścianki są spowodowane różnicami w wykonanych modelach geometrycznych przegrzewacza.

a)

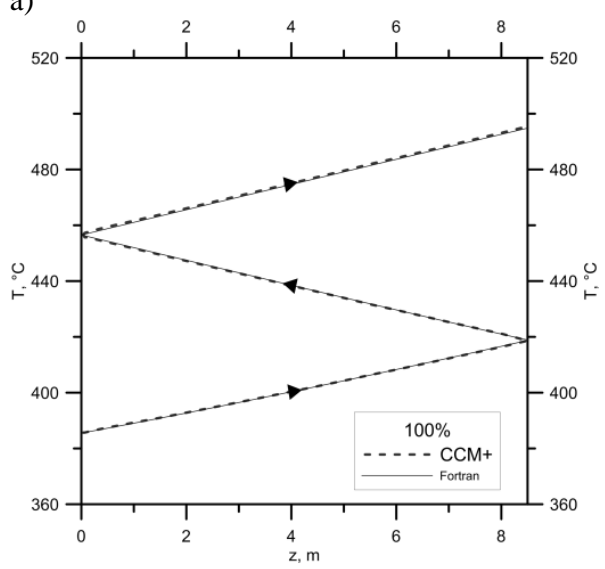

b)

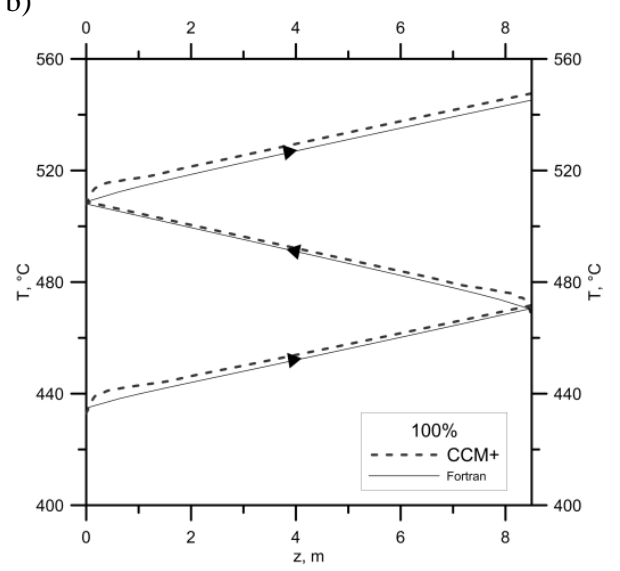

Rys. 6. Zmiana temperatury pary (a) i maksymalnej temperatury materiału (b) na długości przegrzewacza dla obciążenia kotła równego $100 \%$, obliczona za pomocą pakietu CFD (CCM+) i modelu własnego (Fortran)

Fig. 6. Variation of the temperature of the steam (a) and maximum temperature of material (b) along the length of a superheater for the boiler load equal to $100 \%$, calculated using the CFD $(\mathrm{CCM}+)$ program and own subroutine (Fortran) 
a)

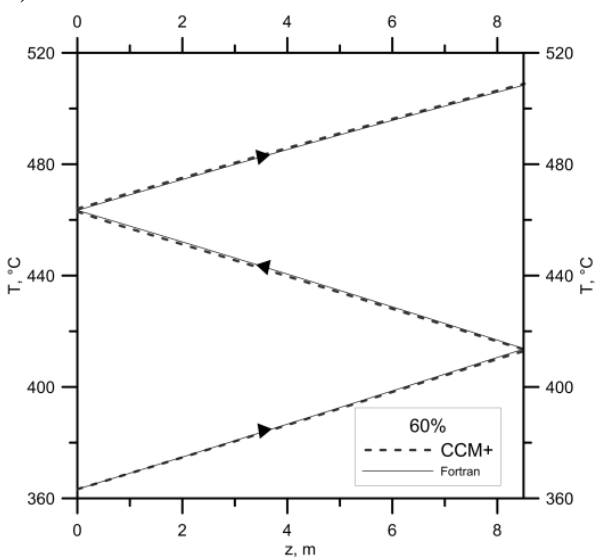

b)

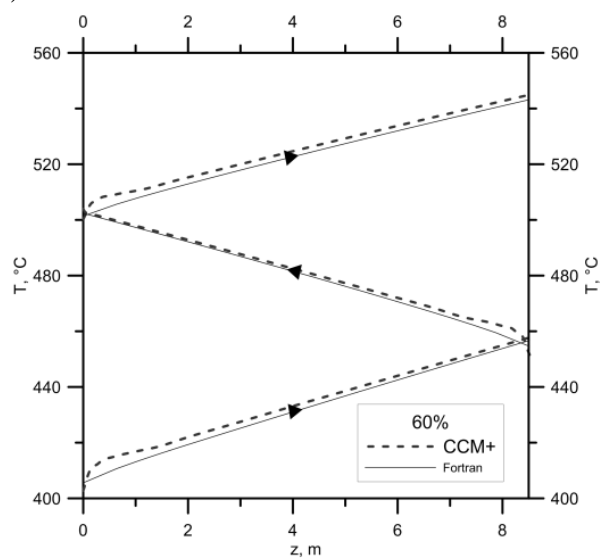

Rys. 7. Zmiana temperatury pary (a) i maksymalnej temperatury materiału (b) na długości przegrzewacza dla obciążenia kotła równego $60 \%$, obliczona za pomocą pakietu CFD (CCM+) i modelu własnego (Fortran)

Fig. 7. Variation of the temperature of the steam (a) and maximum temperature of material (b) along the length of a superheater for the boiler load equal to $60 \%$, calculated using the CFD (CCM+) program and own subroutine (Fortran)

a)

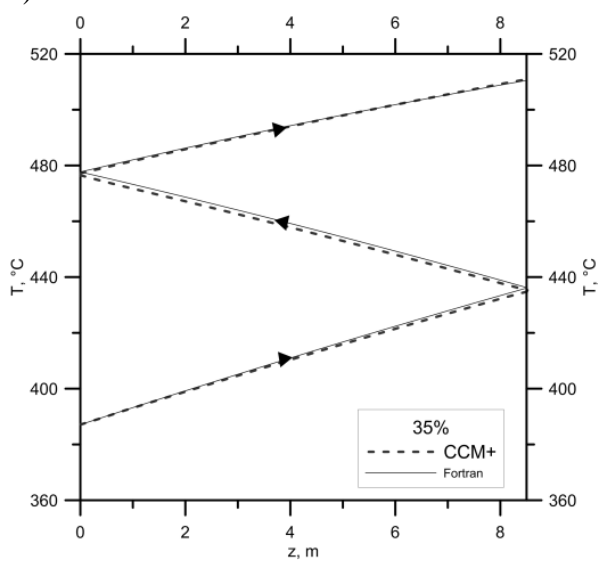

b)

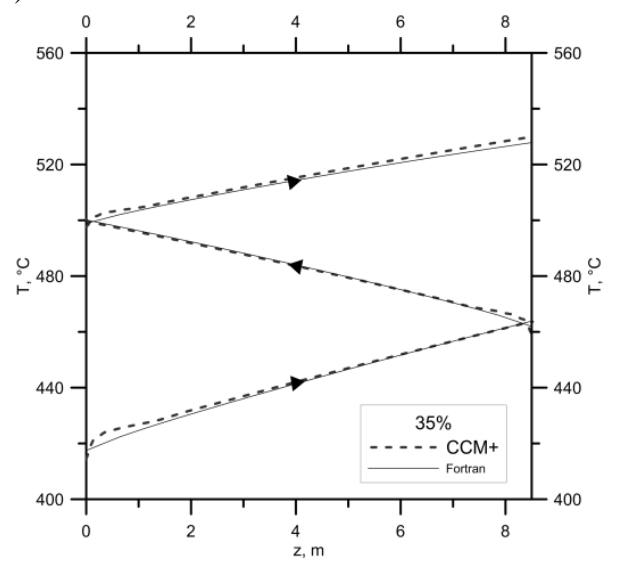

Rys. 8. Zmiana temperatury pary (a) i maksymalnej temperatury materiału (b) na długości przegrzewacza dla obciążenia kotła równego 35\%, obliczona za pomocą pakietu CFD (CCM+) i modelu własnego (Fortran)

Fig. 8. Variation of the temperature of the steam (a) and maximum temperature of material (b) along the length of a superheater for the boiler load equal to $35 \%$, calculated using the CFD $(\mathrm{CCM}+)$ program and own subroutine (Fortran) 
Tabela 1. Zmierzone wartości warunków brzegowych użytych w obliczeniach

Table 1 . The measured values of the boundary conditions used in the calculations

\begin{tabular}{llccc}
\hline Nr & \multicolumn{1}{c}{ Parametr } & \multicolumn{3}{c}{ Wydajność kotła, \% } \\
& & 100 & 60 & 35 \\
\hline 1 & Strumień masy pary, $\mathrm{kg} / \mathrm{s}$ & 0,43 & 0,245 & 0,1485 \\
2 & Ciśnienie pary na wlocie, $\mathrm{MPa}$ & 16 & 10 & 7,5 \\
3 & Temperatura pary na wlocie, ${ }^{\circ} \mathrm{C}$ & 385,5 & 363,3 & 387,1 \\
4 & Temperatura spalin, ${ }^{\circ} \mathrm{C}$ & 850 & 767 & 645 \\
5 & Współczynnik wnikania ciepła po stronie & 174 & 130 & 104 \\
& spalin $(\mathrm{CCM}+), \mathrm{W} /\left(\mathrm{m}^{2} \cdot \mathrm{K}\right)$ & & & \multirow{2}{*}{135,2} \\
6 & $\begin{array}{l}\text { Współczynnik wnikania ciepła po stronie } \\
\left.\text { spalin (Fortran), W/(m }{ }^{2} \cdot \mathrm{K}\right)\end{array}$ & 181,2 & & \\
\hline
\end{tabular}

\section{Podsumowanie}

Model opracowany z zastosowaniem bilansowej metody elementów skończonych pozwolił przeprowadzić obliczenia dla ustalonych stanów pracy przegrzewacza pary. Obliczone temperatury pary na wylocie z poszczególnych biegów (przyrost temperatury pary) oraz maksymalna temperatura materiału uzyskana z wykorzystaniem dwóch modeli (MOS i BMES) są bardzo do siebie zbliżone. W przypadku maksymalnej temperatury materiału wartości uzyskane za pomocą symulacji przy użyciu programu Star-CCM+ i gęstej siatki objętości skończonych są nieznacznie wyższe niż wartości temperatury otrzymane za pomocą własnego modelu matematycznego, w którym liczba objętości skończonych była niewielka. Te nieznaczne różnice $\mathrm{w}$ wartościach temperatury ścianki są spowodowane różnicą $\mathrm{w}$ odwzorowanym modelu geometrycznym przegrzewacza. Uproszczony model geometryczny z zastosowaniem BMES pozwala na przeprowadzanie obliczeń w stanach nieustalonych, przy krótkich czasach obliczeniowych.

\section{Literatura}

[1] Gnielinski V.: On heat transfer in tubes, Int. J. Heat Mass Transfer, 63 (2013), 134$-140$.

[2] Pich R., EVT: Werkstoffkennwerte, Stuttgart 1980.

[3] Star-CCM+ software: User Guide, Computational Dynamics Ltd, London 2011.

[4] Taler D.: Experimental determination of correlations for mean heat transfer coefficients in plate fin and tube heat exchangers, Arch. Thermodyn., 33 (2012), 1-24

[5] Taler D., Korzeń A., Madejski P.: Wyznaczanie temperatury rur w grodziowym przegrzewaczu pary w kotle fluidalnym, Rynek Energii, 93 (2011), 56-60.

[6] Taler J., Duda P.: Solving Direct and Inverse Heat Conduction Problems, Springer, Berlin 2006.

[7] VDI Heat Atlas, 2nd Ed., VDI-Springer, Berlin 2010. 


\section{MODELING OF THE STEADY-STATE THERMAL AND FLOW PROCESSES IN STEAM SUPERHEATER OF FLUIDIZED BOILER}

\section{S u m m a r y}

The paper presents the results of computational steady-state simulations of the superheater. Analyzed superheater is characterized by complex shape of cross-section of tubes and is used in boilers with circulating fluidized (CFD). During the thermal and flow calculations of the superheater with a complex cross-section shape, the temperature distribution of the material need to be determined over the entire length of the superheater. To perform the calculations of superheater operation in the steady state was created its own mathematical model, prepared in Fortran language, which the results were compared with the results obtained in the Star-CCM + software. In this model, to solve the equation of heat conduction was applied the balance finite element method, which allows for the accurate determination of the temperature distribution using a small number of grid cells. To determine the properties of flowing steam the explicit finite difference method was applied. The results obtained by the own model compared with the results obtained by CFD modeling show very good agreement.

Keywords: steam boiler, temperature field, computational fluid dynamics, balance finite element method

DOI: $10.7862 / \mathrm{rm} .2015 .17$

Otrzymano/received: 14.09 .2014 r.

Zaakceptowano/accepted: 21.01.2015 $\mathrm{r}$. 